\title{
Fenotypowanie metaboliczne w rozwoju dietetyki spersonalizowanej
}

\begin{abstract}
STRESZCZENIE
$D^{3}$ eta stanowi ważny modyfikowalny czynnik stylu życia wpływający na ryzyko wystąpienia większości chorób cywilizacyjnych. Prawidłowo dobrana dieta chroni przed rozwojem wielu chorób lub wspomaga ich leczenie. W randomizowanych badaniach klinicznych wykazano, że udzielanie spersonalizowanych porad żywieniowych ma większą skuteczność $\mathrm{w}$ porównaniu do zaleceń uniwersalnych zarówno $\mathrm{w}$ aspekcie zmiany nawyków żywieniowych jak i leczenia otyłości. W zależności od stopnia zróżnicowania zaleceń żywieniowych i dostosowania ich do indywidualnych potrzeb użytkowników wyróżnić można dietetykę stratyfikowaną, spersonalizowaną i precyzyjną. Nowym polem badawczym pomocnym $w$ rozwoju dietetyki spersonalizowanej jest fenotypowanie metaboliczne, które polega na grupowaniu osób na podstawie ich cech metabolicznych. Liczne badania wykazały, że osoby o odmiennych metabotypach inaczej reagują na dietę lub określone interwencje żywieniowe. Artykuł ma na celu przedstawienie aktualnego przeglądu literatury dotyczącej możliwości wykorzystania fenotypowania metabolicznego $\mathrm{w}$ stratyfikacji i personalizacji interwencji dietetycznych. Uwzględniono metody tworzenia fenotypów metabolicznych oraz zaprezentowano badania dotyczące wykorzystania metabotypowania $\mathrm{w}$ dietetyce.
\end{abstract}

\section{WPROWADZENIE}

Dostępność wysokoprzepustowych narzędzi badawczych (technologii „omicznych") oraz metod analizy big data umożliwia rozwój medycyny spersonalizowanej, której powszechność w nadchodzących dekadach stanie się coraz bardziej realna. Indywidualizacja znajduje swoje miejsce w obszarze leczenia, diagnostyki i prewencji. Dieta jest jednym z najważniejszych modyfikowalnych czynników kształtujących ryzyko rozwoju wielu chorób przewlekłych w szczególności cukrzycy, otyłości, chorób układu sercowo-naczyniowego i nowotworów $[1,2]$. Coraz większe znaczenie przypisuje się międzyosobniczym różnicom $\mathrm{w}$ odpowiedzi na określone interwencje żywieniowe lub składniki pokarmowe, które wynikają z różnic fenotypowych i uwarunkowań genetycznych $[1,3]$. Wskazuje to na potrzebę stratyfikacji, a idąc dalej personalizacji zaleceń żywieniowych. Działania mające na celu opracowanie zindywidualizowanych strategii żywieniowych długo skupiały się wokół nutrigenetyki i nutrigenomiki. Jednak coraz częściej zwraca się uwagę na fakt, że podłoże genetyczne stanowi tylko jedną z wielu zmiennych kształtujących reakcję organizmu na określoną dietę lub składniki pokarmowe. Inne istotne czynniki to cechy antropometryczne, markery biochemiczne, płeć, wiek, skład mikrobioty jelitowej, nawyki żywieniowe, skład posiłków [4]. Jednym z obiecujących kierunków rozwoju dietetyki spersonalizowanej jest możliwość wykorzystania technik metabotypowania (fenotypowanie lub profilowanie metaboliczne) czyli grupowania osób na podstawie podobieństw ich cech metabolicznych. Jest to nowatorska koncepcja, która została wprowadzona niespełna dekadę temu i jest $\mathrm{w}$ różny sposób definiowana $[1,5]$. Ideą metabotypowania jest identyfikacja metabotypów w oparciu o takie czynniki jak dieta, dane metabolomiczne, cechy antropometryczne, parametry kliniczne, czy skład ilościowy i jakościowy mikrobioty jelitowej [1]. Podstawowych narzędzi do tworzenia fenotypów metabolicznych dostarcza metabolomika, która zajmuje się badaniem metabolomu, czyli zestawu wszystkich metabolitów zawartych w lub wydzielanych z określonej tkanki lub typu komórek [6]. Metabotypowanie znalazło zastosowanie m.in. w badaniu toksyczności i

dział genetyki zajmujący się wpływem zróżnicowania genetycznego na odpowiedź organizmu w wyniku interwencji żywieniowej lub ryzyka chorób dietozależnych, nutrigenomika - dziedzina nauki zajmująca się badaniem wpływu diety lub składników pokarmowych na ekspresję genów w celu opracowania indywidualnej diety, proteomika - dziedzina nauki zajmująca się badaniem struktury, lokalizacji, funkcji oraz zależności między białkami, transkryptomika - dziedzina nauki zajmująca się badaniem ekspresji genów.

Finansowanie: Praca finansowana z grantu MNiSW nr 019/RID/2018/19 przyznanego w ramach programu Regionalna Inicjatywa Doskonałości.

\section{mgr Mateusz Grabowski ${ }^{1,2}$,}

prof. dr hab. n.med. Jarosław Barski $^{1,2}$,

dr n. med. Daniela Liśkiewicz $^{1,3} \square$

${ }^{1}$ Centrum Medycyny Doświadczalnej, Śląski Uniwersytet Medyczny w Katowicach ${ }^{2}$ Katedra i Zakład Fizjologii, Wydział Nauk Medycznych w Katowicach, Śląski Uniwersytet Medyczny w Katowicach ${ }^{3}$ Laboratorium Badań Molekularnych, Instytut Badawczo - Rozwojowy Fizjoterapii i Nauk o Zdrowiu, Akademia Wychowania Fizycznego im. J. Kukuczki w Katowicach

https://doi.org/10.18388/pb.2020_329

๑autor korespondujący: d.liskiewicz@awf.katowice.pl

Słowa kluczowe: dietetyka spersonalizowana, fenotypowanie metaboliczne, metabotypowanie, metabolomika, metabotyp, metabolom

Wykaz skrótów: APOE4 - apolipoproteina E4; BMI - wskaźnik masy ciała; CHOP - Europejski projekt otyłości dziecięcej; GS-MS - chromatografia gazowa sprzężona ze spektrometrią mas; HDL-C - frakcja cholesterolu C; LC-MS - chromatografia cieczowa sprzężona ze spektrometrią mas; NMR - magnetyczny rezonans jądrowy; MS - spektrometria mas

Słowniczek pojęć: eksposom - zespół czynników środowiskowych oddziałujących na organizm, fenotyp - zestaw cech organizmu, zależny od genotypu, obejmujący głównie cechy morfologiczne, fizjologiczne oraz behawioralne, genotyp - zestaw genów osobnika, warunkujący dziedziczenie cech, metabolom - zestawu wszystkich metabolitów organizmu będących składnikami szlaków metabolomicznych, metabolomika - dziedzina nauki zajmująca się analizą ilościową i jakościową metabolitów, które tworzą metabolom, metabotypowanie - (syn fenotypowanie, profilowanie metaboliczne) grupowanie osób na podstawie podobieństw ich cech metabolicznych, metabotypy - grupy podobnych metabolicznie osób dobranych na podstawie kombinacji określonych metabolitów, reagujących w taki sam sposób na interwencję żywieniową, mikrobiomika - nauka zajmująca się badaniem wpływu ilościowego i jakościowego mikrobioty jelitowej bytującej w przewodzie pokarmowym, nutrigenetyka - 
metabolizmu leków, diagnostyce chorób oraz w dietetyce [7].

W pracy przedstawiono aktualny stan wiedzy dotyczący możliwości wykorzystania fenotypowania metabolicznego w stratyfikacji i personalizacji interwencji dietetycznych. Uwzględniono metody tworzenia fenotypów metabolicznych oraz zaprezentowano badania dotyczące wykorzystania metabotypowania w dietetyce. Należy podkreślić, że istotnym elementem badań nad metabotypami jest ocena roli mikrobioty jelitowej $w$ ich kształtowaniu, jednak temat ten wykracza poza zakres niniejszej pracy.

\section{SPERSONALIZOWANE PODEJŚCIE ŻYWIENIOWE}

Idea zindywidualizowanego podejścia żywieniowego, czyli udzielania porad dietetycznych dostosowanych do potrzeb jednostki, sięga lat 70 XX. wieku [8]. Jednak dopiero zsekwencjonowanie ludzkiego genomu (2001) oraz następująca wzrastająca dostępność tzw. technologii omicznych (genomika, transkryptomika, metabolomika, proteomika) urealniły wizje spersonalizowanej opieki zdrowotnej z dietetyką włącznie [6,9]. Idea personalizacji kontrastuje $\mathrm{z}$ koncepcją udzielania uniwersalnych porad żywieniowych kierowanych do ogółu populacji. Pierwszym stopniem uszczegółowienia zaleceń żywieniowych jest tzw. stratyfikowane lub dostosowane (ang. tailored) podejście żywieniowe. Pojęcia te są bliskoznaczne i odnoszą się do podejścia, którego celem jest grupowanie osób na podstawie podobieństwa ich cech i dostosowywanie programów żywieniowych dla każdej z grup [10]. Terminy dietetyka precyzyjna i spersonalizowana często używane są naprzemiennie, jednakże wielu autorów zwraca uwagę na ich odmienność. W środowisku brakuje konsensusu co do standardów używania tych terminów jak również powszechnie przyjętej definicji [11]. Cześć autorów ściśle wiąże podejście spersonalizowane z predyspozycjami uwarunkowanymi genetycznie podczas gdy $\mathrm{w}$ dietetyce precyzyjnej dopatruje się podejścia łączącego rolę genotypu i fenotypu oraz czynników społecznych i środowiskowych [12]. W dużej części artykułów naukowych nie wprowadza się wyraźnego rozgraniczenia między pojęciami dietetyki spersonalizowanej i precyzyjnej oraz używa się tych pojęć wymiennie (np. [13,14]). Podobna dyskusja toczy się $\mathrm{w}$ kontekście medycyny spersonalizowanej i precyzyjnej. Zgodnie ze stanowiskiem National Research Council (USA) preferuje się używanie terminu medycyna precyzyjna ze względu na możliwą błędną interpretację słowa „spersonalizowana”, które mogłoby sugerować istnienie postępowania terapeutycznego odpowiedniego dla określonej osoby i tylko dla niej. Natomiast nowsze pojęcie „medycyna precyzyjna” odnosi się do działań pozwalających ocenić, które postępowanie terapeutyczne będzie najlepsze dla jednostki uwzględniając uwarunkowania genetyczne, środowiskowe i te związane ze stylem życia [15]. Wyżej opisane koncepcje udzielania porad dietetycznych przedstawiono schematycznie na rycinie 1 .

Przechodzenie od dietetyki stratyfikowanej do spersonalizowanej/precyzyjnej polega na wzrastającym różni-

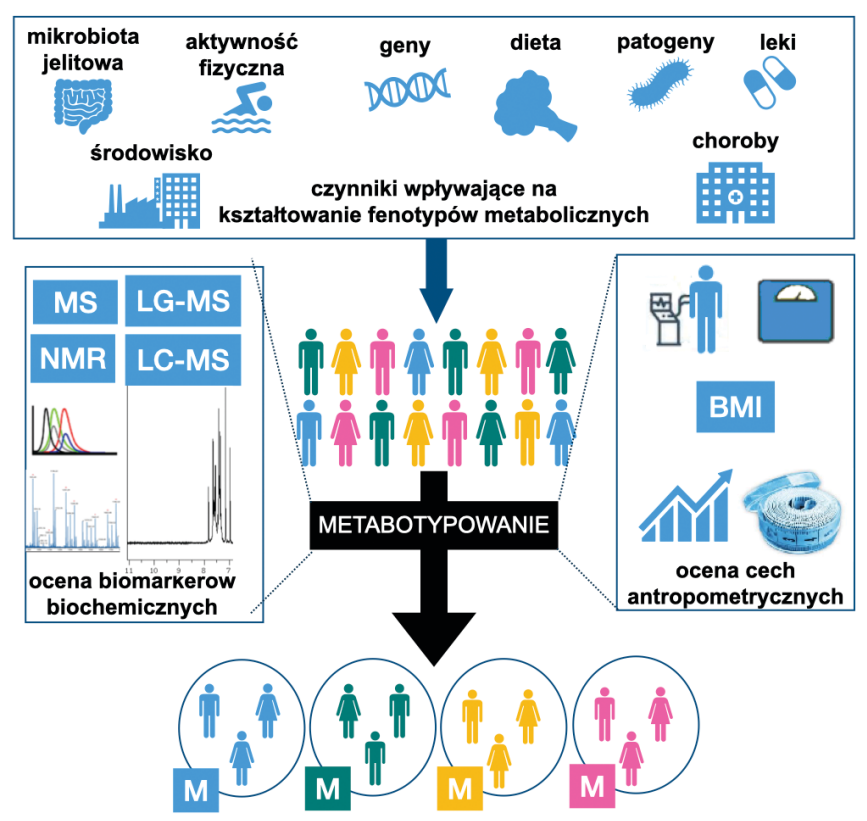

Rycina 1. Strategie doboru interwencji żywieniowych o różnym stopniu dostosowania do indywidualnych cech użytkowników.

cowaniu zaleceń żywieniowych w zależności od potrzeb użytkowników i wymaga zastosowania coraz bardziej zaawansowanych technik diagnostycznych i analizy danych. Początkowo dietetyka spersonalizowana związana była głównie z nutrigenetyką, która bada wpływ zróżnicowania genetycznego na odpowiedź organizmu na określaną interwencję żywieniową lub ryzyko wystąpienia chorób dietozależnych [9]. Jednak szybko do rozwoju dietetyki spersonalizowanej zaczęły przyczyniać się inne technologie "omiczne" tj. nutrigenomika, zajmująca się badaniem wpływu diety lub składników pokarmowych na ekspresję genów, proteomika, metabolomika, epigenomika i mikrobiomika pozwalające na badanie odpowiednio: całości białek i metabolitów organizmu, regulacji epigenetycznych oraz mikroorganizmów bytujących w przewodzie pokarmowym [10].

Indywidualizacja zaleceń żywieniowych może odbywać się na kilku poziomach, z których każdy stanowi podstawę kolejnego. Na pierwszym poziomie zalecenia dostosowywane są na podstawie informacji o nawykach żywieniowych jednostki, na drugim dodatkowo na podstawie danych antropometrycznych i badań klinicznych (np. BMI, poziom glukozy czy cholesterolu we krwi), a na trzecim na podstawie diety, fenotypu i genotypu [16].

Koncepcja dietetyki spersonalizowanej/precyzyjnej opiera się na założeniu, że takie podejście charakteryzuje się większą skutecznością w porównaniu z zaleceniami opartymi o uniwersalne zasady zdrowego żywienia [17-19]. Skuteczność może być rozpatrywana w aspekcie efektu biologicznego lub behawioralnego (zmiany nawyków żywieniowych). W kilku randomizowanych badaniach klinicznych, w większości opartych o interwencje przeprowadzane przez Internet, wykazano, że personalizacja/stratyfikacja zaleceń dietetycznych skutkuje 
większą skutecznością promowania zmiany nawyków żywieniowych [19-25]. W innych badaniach pokazano, że takie podejście prowadzi do większej utraty masy ciała [1,26-31]. Badania te zostały wnikliwie przedyskutowane w pracy przeglądowej O’Donovan i wsp. [9].

Z kolei badania oceniające skuteczność spersonalizowanego podejścia żywieniowego opartego o predyspozycje genetyczne dają sprzeczne wyniki zarówno w aspekcie zmiany nawyków żywieniowych, jak i efektu biologicznego [32-37]. Informacja genetyczna już od wielu lat sprawdza się bardzo dobrze w terapii żywieniowej fenyloketonurii i innych wrodzonych zaburzeń metabolizmu [38] czy np. chorobie De Vivo spowodowanej mutacją w genie transportera glukozy GLUT1 [39]. Jednak poza tymi przypadkami, w których niestosowanie diety skutkuje natychmiastowym pojawieniem się lub nawrotem objawów choroby, posiadanie informacji o predyspozycjach genetycznych wydaje się nie mieć znaczącego wpływu na zachowania żywieniowe w długim okresie [40]. Wyjątkiem jest badanie, które wykazało, że pacjenci poinformowani o tym, że mają zwiększone prawdopodobieństwo rozwoju choroby Alzheimera (APOE4 pozytywni) wykazywali pozytywną zmianę nawyków żywieniowych w porównaniu z pacjentami bez obciążenia genetycznego [41]. Dwie prace przeglądowe ( $w$ tym jeden przegląd systematyczny Cochrane) konkludują, że brak jest klinicznych dowodów potwierdzających że znajomość genotypu motywuje do zmiany nawyków żywieniowych, a zatem nieuzasadnione jest opieranie rekomendacji dietetycznych o predyspozycje genetyczne $[42,43]$.

Skuteczność dietetyki spersonalizowanej wydaje się więc być dobrze udokumentowana w podejściach opisanych jako poziom 1 i 2 personalizacji. Wzrasta również ilość danych wskazujących na to, że odpowiedź organizmu na dietę kształtowana jest przez wiele zmiennych, wśród których duże znaczenie odgrywają cechy fenotypowe [44]. W obliczu powyższego kilka zespołów badawczych (Institute of Food \& Health, University College Dublin; Human Nutrition Research Centre, Newcastle University, Newcastle upon Tyne; Institute of Epidemiology II, German Research Center for Environmental Health, Neuherberg) zaproponowało indywidualizację podejścia dietetycznego opartą o fenotypowanie metaboliczne $[3,9,45]$.

\section{FENTOTYPOWANIE METABOLICZNE}

Fenotypem określa się zespół jakościowych i ilościowych wartości cech organizmu. Fenotyp stanowi produkt interakcji między genami a środowiskiem i podlega nieustannym zmianom w życiu organizmu [7]. Na fenotyp mają wpływ różne czynniki, takie jak: genotyp, regulacja ekspresji genów, eksposom czyli wszystkie czynniki środowiskowe, które oddziałują na organizm oraz aktywność drobnoustrojów bytujących w przewodzie pokarmowym [3,7]. Profil metaboliczny stanowi integralną część opisu fenotypowego organizmu i również zależy od działania wszystkich tych czynników [7]. Matabolomika zajmuje się profilowaniem metabolicznym, czyli kompleksową analizą umożliwiająca identyfikację i kwanty- fikację wszystkich matabolitów obecnych w określonym układzie biologicznym. Najczęściej wykorzystuje się do tego takie metody badawcze jak magnetyczny rezonans jądrowy (ang. nuclear magnetic resonance, NMR), spektrometrię mas (ang. mass spectrometry, MS) lub chromatografię cieczową/gazową sprzężoną z MS (LC-MS/GS-MS, z ang. A liquid chromatography - mass spectrometry/A gas chromatography-mass spectrometry) [7,46,47]. Zdefiniowanie zestawu biomarkerów charakterystycznych dla fenotypu związanego z określonym stanem fizjologicznym lub patologicznym pozwala na zgłębienie wiedzy o mechanizmach warunkujących wystąpienie tego stanu. Ponadto po zwalidowaniu, zidentyfikowany zestaw markerów może służyć jako narzędzie diagnostyczne lub prognostyczne [7]. Przy zastosowaniu narzędzi statystycznych, najczęściej algorytmu k-średnich i hierarchicznej analizy klastrów dane metaboliczne oraz inne cechy fenotypowe można wykorzystać do zdefiniowania metabotypów [9]. Profilowanie metaboliczne przeprowadza się wykorzystując metabolity zawarte w płynach ustrojowych, takich jak mocz lub osocze, rzadziej wykonuje się biopsję tkanek (ze względu na duży stopień inwazyjności) [46]. Metabolity występujące w płynach biologicznych człowieka mogą pochodzić z kilku źródeł. Mogą być wytworzone przez komórki gospodarza, przez mikroogranizmy, paso-
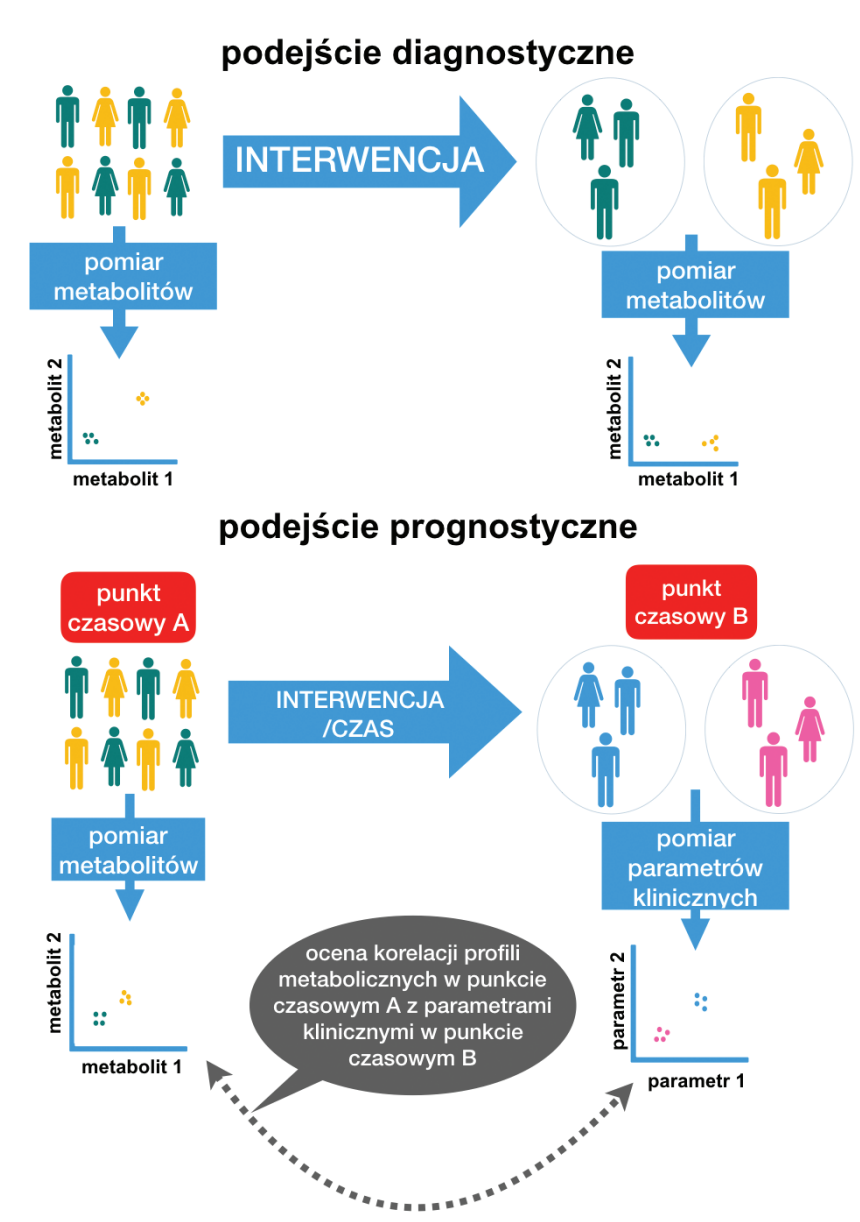

Rycina 2. Graficzne przedstawienie koncepcji fenotypowania metabolicznego. MS - spektrometria mas, LC-MS - chromatografia cieczowa sprzężona z spektrometria mas, LG-MS - chromatografia gazowa sprzężona ze spektrometrią mas, NMR - magnetyczny rezonans jądrowy, BMI - wskaźnik masy ciała, M1 - M4 - metabotyp 1-4. 
żyty lub pochodzić z metabolizmu pożywienia czy leków [7]. Powyżej opisaną koncepcję metabotypowania przedstawiono na rycinie 2 .

Kluczowym elementem $\mathrm{w}$ fenotypowaniu metabolicznym jest sposób pomiaru metabolitów. Everett i wsp. [7] przedstawili cztery koncepcje pomiaru metabolitów: (I) badanie stężenia metabolitów, (II) śledzenie zmian ilości metabolitów w czasie, (III) entropię metaboliczną oraz (IV) czasoprzestrzenne zależności między metabolitami i sieci metabolitów. Najczęściej w badaniach klinicznych, angażujących fenotypowanie metaboliczne wykorzystuje się pomiar stężenia metabolitów, np. przed i po interwencji. Jeśli zmiany w stężeniu metabolitów korelują $\mathrm{z}$ wynikami badań klinicznych metabolity te kandydują do pełnienia roli biomarkerów. Bardziej zaawansowanym podejściem jest sprawdzanie losów metabolitów w szlakach biochemicznych w różnych punktach czasowych. Pomiary są wykonywane seryjnie począwszy od okresu poprzedzającego interwencję, $\mathrm{w}$ trakcie interwencji oraz po niej. Śledzenie trajektorii metabolitu lub grupy metabolitów daje więcej informacji o odpowiedzi jednostki na określoną ingerencję.

Trzecia koncepcja przedstawiona przez zespół Everett'a wykorzystuje entropię metaboliczną. Jest to stosunkowo nowy i innowacyjny sposób analizy fenotypów metabolicznych. Poprzez entropię metaboliczną rozumie się stopień rozrzutu cechy metabolitu (np. koncentracji) w obrębie organizmu lub populacji. Koncepcja ta opiera się na założeniu, że w warunkach fizjologicznych entropia metaboliczna jest względnie niska, co wynika z działania mechanizmów odpowiedzialnych za utrzymanie homeostazy. W takiej sytuacji stężenia metabolitów w stałym środowisku zazwyczaj nie zmieniają się znacząco. Tymczasem $w$ warunkach patofizjologicznych system kontroli homeostatycznej przestaje $\mathrm{w}$ pełni prawidłowo funkcjonować, co prowadzi do wzrostu entropii metabolicznej. Relatywnie wyższa entropia metaboliczna może być więc interpretowana jako cecha metabotypu o wyższym ryzyku zachorowania. Natomiast, koncepcja zależności, korelacji i sieci metabolitów zakłada, że w każdym układzie biologicznym w wyniku działania czynników zewnętrznych lub wewnętrznych może dochodzić do zaburzenia homeostazy metabolicznej. Zmiany określonych metabolitów skutkują zmianami innych. Analiza zmian poziomów różnych metabolitów, korelacji i zależności między nimi jest możliwa poprzez zastosowanie zaawansowanych metod spektroskopii statystycznej (ang. statistical spectroscopy methods) [7].

Ze względu na rodzaj układu eksperymentalnego fenotypowanie metaboliczne może mieć charakter diagnostyczny (interwencyjny) lub prognostyczny. W pierwszym przypadku poziomy metabolitów są mierzone przed i po interwencji, a obserwowane zmiany są interpretowane $\mathrm{w}$ jej kontekście. Podejście to wymaga występowania różnic pomiędzy badanymi próbami przed interwencją co pozwala na ocenę efektu zastosowanego działania w zależności od stanu wyjściowego. Interwencją może być np. podanie leku, spożycie określonego posiłku (ang. nutritional challange) lub bodziec fizjologiczny, patologiczny itp [7]. Podejście prognostyczne wykorzystuje ocenę metabolitów przed interwencją do przewidywania rezultatów po interwencji (przy czym interwencją może być jedynie upływ czasu). Znajduje ono zastosowanie $\mathrm{w}$ przewidywaniu efektywności potencjalnej terapii, zastosowanej diety lub ryzyka wystąpienia określonej choroby, gdyż metabolity mogą ujawniać informacje o zmianach patologicznych na długo przed wystąpieniem objawów klinicznych [6]. Graficzne przedstawienie podejść diagnostycznego i prognostycznego w badaniach nad fenotypowaniem metabolicznym przedstawiono na rycinie 3 . W tabeli 1 przedstawiono zestawienie badań przeprowadzonych $\mathrm{z}$ wykorzystaniem fenotypowania metabolicznego o charakterze diagnostycznym lub prognostycznym. Wybrane badania opisano w kolejnych podrozdziałach.

\section{METABOTYPOWANIE W BADANIACH DIAGNOSTYCZNYCH}

Podejście interwencyjne do metabotypowania zastosowano z powodzeniem $\mathrm{w}$ badaniach $\mathrm{z}$ zakresu żywienia wykazując, że osoby w populacji można grupować w metabotypy według reakcji metabolicznych na żywność i zmiany w diecie $[47,48]$. Hjorth i wsp. porównywali różne diety stosowane w leczeniu nadwagi i otyłości, zakładając, że jedna strategia dietetyczna byłaby odpowiednia dla wszystkich otyłych. Autorzy nie dostarczyli mocnych dowodów na skuteczność jakiejkolwiek konkretnej diety i zaproponowali hipotezę, że ludzie osiągną inne poziomy sukcesu stosując różne diety. Na podstawie retrospektywnych analiz interwencji dietetycznych zaproponowali, że stężenie glukozy w osoczu i/lub insuliny na czczo przed interwencją mogą służyć jako prognostyczne markery utraty masy ciała w okresach, w których znany jest skład diety badanego. Na podstawie poziomu glukozy na czczo wyodrębnili trzy metabotypy - normoglikemiczny, przedcukrzycowy i cukrzycowy, które reagowały w odmienny sposób na różne diety [48]. Zauważyli, że osoby z podwyższonym stężeniem glukozy na czczo lepiej reagują na diety bogate $\mathrm{w}$ błonnik i o niskim indeksie

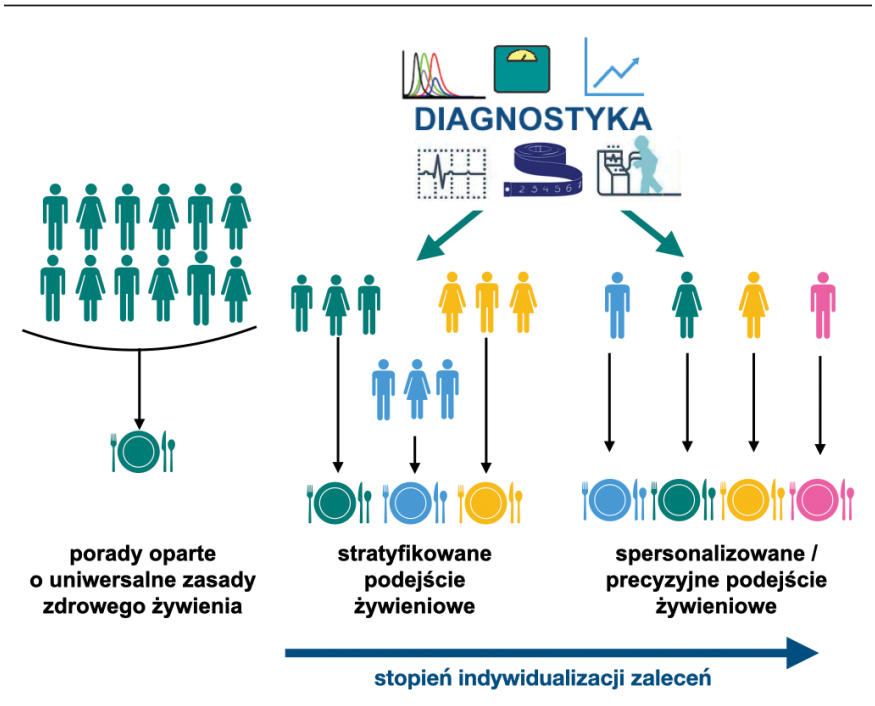

Rycina 3. Graficzne przedstawienie podejść diagnostycznego i prognostycznego $\mathrm{w}$ badaniach nad fenotypowaniem metabolicznym. 
Tabela 1. Badania z zastosowaniem fenotypowania metabolicznego o charakterze diagnostycznym i prognostycznym.

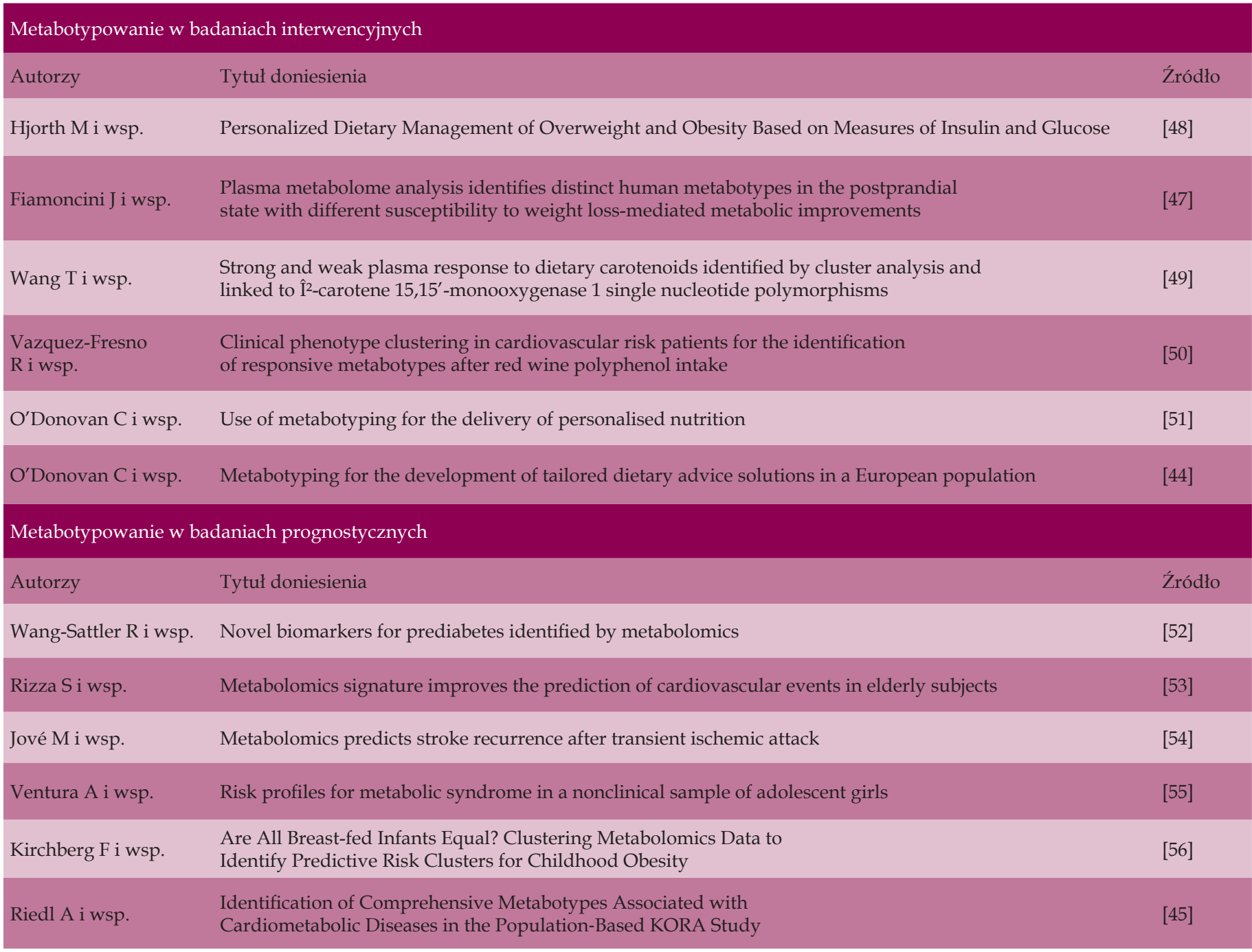

glikemicznym [57-62]. Natomiast analizując inne badania Hjorth i wsp. potwierdzili, że osoby z dużym stężeniem insuliny na czczo korzystają z diet o niskim indeksie glikemicznym, podczas gdy osoby $\mathrm{z}$ niskimi stężeniem insuliny na czczo nie wydają się różnić pod względem odpowiedzi na różne diety [63-69]. Powyższe badania zostały szczegółowo przedyskutowane w pracy Hjorth i wsp. [48]. Badania Fiamonicini i wsp. na zdrowych osobach pokazują, że kompleksowe skategoryzowanie około 300 metabolitów (fosfolipidy $n=90$, sfingolipidy $n=15$, acylokarcyny $n=40$, aminokwasy $i$ amidy biogenne $n=41$ oraz wszystkie heksozy w osoczu), może wyłonić metabotypy, które reagują w odmienny sposób na dietę. Autorzy zauważyli również, że markery metabolizmu lipidów mogą umożliwić wczesne wykrycie zespołu metabolicznego [46]. Wang i wsp. w badaniu z udziałem zdrowych osób w przedziale wieku 36-69 lat zidentyfikowali grupy osób o odmiennej odpowiedzi na napoje bogate w karotenoidy. Po 3 tygodniach codziennego spożywania soku pomidorowego lub arbuzowego, dzięki analizie klastrów zidentyfikowali grupy osób, które silnie lub słabo reagują na spożywanie karotenoidów. Ponadto indywidualna reakcja na karotenoidy była powiązana $\mathrm{z}$ wariantami genu BCO1 (kodującego enzym 15,15'-monooksygenazę $1 \beta$-karotenu). Wyniki te potwierdzają koncepcję, że osoby w różny sposób przyswajają lub metabolizują karotenoidy. Sugeruje to, że biodostępność karotenoidów może obejmować określone warianty genetyczne enzymu $15,15^{\prime}$-monooksygenazy $1 \beta$-karotenu. Autorzy stwierdzili również, że zróżnicowane przyswajanie karotenoidów, może stanowić podstawę do udzielania bardziej precyzyjnych porad dietetycznych [49]. W badaniu prowadzonym przez Vazquez-Fresna i wsp. stwierdzono różną odpowiedź na polifenole z czerwonego wina u osób w wieku $\geq 55$ lat $\mathrm{z}$ wysokim ryzykiem sercowo-naczyniowym. Badano stężenie metabolitów we krwi i moczu na czczo oraz parametry antropometryczne. Na podstawie algorytmu k-średnich i analizy dyskryminacyjnej metodą cząstkowych najmniejszych kwadratów z filtrowaniem ortogonalnej korekty sygnału (OSC-PLS-DA) pogrupowano osoby w cztery metabotypy, wśród nich wyodrębniono grupę podwyższonego ryzyka wystąpienia chorób sercowo - naczyniowych. Po 28 dniach spożywania czerwonego wina (zawartość polifenoli $=733$ równoważników kwasu galusowego / dzień) zauważono, że stężenie 4-hydroksyfenylooctanu w moczu znacznie wzrosło w 
zdrowszym metabotypie $\mathrm{w}$ porównaniu $\mathrm{z}$ metabotypem podwyższonego ryzyka, co wskazuje na zróżnicowaną odpowiedź w tych grupach [70].

\section{METABOTYPOWANIE W BADANIACH PROGNOSTYCZNYCH}

Zasadność stosowania podejścia prognostycznego udowodniono $\mathrm{w}$ badaniach longitudinalnych. Badania Wang-Sattler i wsp. przedstawiają zastosowanie fenotypowania metabolicznego do identyfikacji biomarkerów stanu przedcukrzycowego z upośledzoną tolerancją glukozy. Po zbadaniu 140 metabolitów we krwi autorzy wyłonili trzy - glicynę, lizofosfatydylocholinę i acetylokarnitynę, które charakteryzowały się niższym stężeniem $\mathrm{u}$ osób z upośledzoną tolerancją glukozy. Stężenia tych związków w okresie prognostycznym korelowały z pojawieniem się początkowych objawów cukrzycy typu II [52]. W innych badaniach potwierdzono zastosowanie metabotypowania do klinicznego prognozowania zdarzeń sercowo - naczyniowych oraz udaru mózgu [53,54]. Badania Ventura i wsp. dotyczyły oceny ryzyka wystąpienia zespołu metabolicznego u dziewcząt, które obserwowano od 5 do 13 roku życia. Badano sześć czynników ryzyka zespołu metabolicznego, takich jak: obwód w talii, skurczowe i rozkurczowe ciśnienie krwi, HDL-C, triacyloglicerole i poziom glukozy we krwi. Grupa z wyższym ryzykiem zespołu metabolicznego miała najwyższy wskaźnik BMI na początku badania (w wieku 5 lat). W okresie obserwacji badani z tej grupy, jak i z grupy ryzyka nadciśnienia tętniczego mieli znacznie większy przyrost masy ciała i ilości tkanki tłuszczowej. Dodatkowo grupa o wyższym ryzyku zespołu metabolicznego miała najwyższe dzienne spożycie napojów słodzonych [55]. Wyniki tego badania potwierdzają rolę metabotypów w identyfikowaniu osób o podwyższonym ryzyku i stanowią podstawę do opracowywania ukierunkowanych porad zdrowotnych i dietetycznych [2]. Europejski projekt otyłości dziecięcej (ang. European Childhood Obesity Project, CHOP) zakładał klasyfikację zdrowych niemowląt (n = 154) $\mathrm{w}$ wieku 6 miesięcy do dwudziestu metabotypów na podstawie badania 21 aminokwasów i 146 lipidów w celu przewidywania ryzyka wystąpienia otyłości. Analizowano jedynie cztery najliczniejsze metabotypy $(n \geq 14)$. W wieku 6 lat obserwowano tendencję do różnic w BMI pomiędzy klastrami. Uzyskane wyniki potwierdzają koncepcję, że grupowane na podstawie różnic fenotypowych możliwe jest już na bardzo wczesnym etapie rozwoju [56]. Kolejnym przykładem zastosowania metabotypów w prospektywnych badaniach jest projekt KORA F4 (Kooperative Gesundheitsforschung in der Region Ausburg), w którym badano 1729 dorosłych w przedziale wieku 32-77 lat. Mierzono wskaźnik BMI i trzydzieści trzy markery biochemiczne. Badaną populację podzielono na trzy metabotypy. Dwukrotnie określano stan zdrowia badanych, na początku i po 7 latach trwania projektu. Grupa wysokiego ryzyka miała najbardziej niekorzystny profil biomarkerów (najwyższy wskaźnik BMI i największa częstość występowania chorób kardiometabolicznych), a także najwyższą częstość występowania nadciśnienia, cukrzycy typu 2, hiperurykemii i dyslipidemii na początku badania [45]. Autorzy dostarczyli mocnych dowodów na to, że metabotypowanie jest solidnym podejściem do identyfikowania grup osób, jako beneficjentów strategii zapobiegania chorób kardiometabolicznych.

\section{ZASTOSOWANIE METABOTYPOWANIA W DIETETYCE SPERSONALIZOWANEJ}

O' Donovan i wsp. zaproponowali dwa przykłady użycia fenotypowania metabolicznego $\mathrm{w}$ personalizacji zaleceń żywieniowych. W 2015 r. autorzy przedstawili strukturę podziału badanej populacji na trzy metabotypy z wykorzystaniem czterech powszechnych markerów metabolicznych (triacyloglicerolu, cholesterolu całkowitego, frakcji cholesterolu HDL-C i glukozy). Osoby z metabotypu I miały wysokie stężenie triacylogliceroli, a z metabotypu II odpowiednie stężenia wszystkich czterech metabolitów. W metabotypie III znalazły się osoby o najbardziej niekorzystnym profilu metabolicznym przy wysokich stężeniach triacylogliceroli, cholesterolu całkowitego i glukozy oraz najniższym stężeniu frakcji cholesterolu HDL-C. Dla każdego metabotypu opracowano ukierunkowane porady żywieniowe. W celu sprawdzenia wiarygodności zaproponowanego podejścia porównano go $\mathrm{z}$ indywidualnym planem opracowanym przez dietetyka bez metabotypowania. Średnie dopasowanie między metodami wynosiło 89,1\%, przy czym dla dwóch trzecich uczestników wykazano 100\% dopasowania planów żywieniowych [51]. Zaletą przedstawionej przez zespół O’Donovan koncepcji jest łatwość jej realizacji w placówkach lecznictwa ambulatoryjnego i podstawowej opieki zdrowotnej. Metabotypowanie przeprowadzono oceniając cztery metabolity, których oznaczenie w krwi jest stosunkowo szybkie i tanie oraz powszechnie wykonywane.

W 2017 r. O' Donovan i wsp. przedstawili inny przykład spersonalizowanego podejścia żywieniowego przy użyciu metod fenotypowania metabolicznego dla bardziej zróżnicowanej populacji. Celem badania było zidentyfikowanie metabotypów w populacji europejskiej oraz opracowanie ukierunkowanych rozwiązań w zakresie porad dietetycznych dla tych metabotypów i porównanie ich ze spersonalizowanymi poradami dietetycznymi zaproponowanymi w badaniu Food4Me (uczestnicy otrzymywali zindywidualizowane porady dietetyczne oparte na trzech poziomach personalizacji [17]). Wyodrębniono trzy metabotypy. Selekcji dokonano na podstawie dwudziestu siedmiu metabolitów pobieranych z krwi (całkowitego cholesterolu, procentowego udziału wybranych kwasów tłuszczowych i karotenoidów), demografii i pięciu kluczowych składników odżywczych (chlorku sodu, żelaza, wapnia, kwasu foliowego i błonnika). Metabotyp I charakteryzował się najwyższym stężeniem cholesterolu całkowitego i kwasów tłuszczowych trans oraz najniższym stężeniem kwasów omega-3. Został on uznany za metabotyp metabolicznie niezdrowy. Metabotyp II oznaczono jako grupę zdrową, ponieważ osoby w tym metabotypie miały najwyższe średnie stężenie kwasów omega-3 i stężenie karotenoidów oraz najniższe stężenie wolnych kwasów tłuszczowych. Osoby przydzielone do metabotypu III miały najniższe stężenie cholesterolu całkowitego i najwyższe kwasu stearynowego. Opracowano 
ukierunkowane rozwiązania dotyczące porad dietetycznych dla wskazanych metabotypów. Rezultaty porównano z wynikami uczestników otrzymujących spersonalizowane porady dietetyczne dostarczone przez dietetyków w ramach badania Food $4 M e$. Stwierdzono średnie dopasowanie w wysokości $82 \%$ na poziomie dostarczania tych samych porad dietetycznych. Wyniki uzyskane przez $\mathrm{O}^{\prime}$ Donovan i wsp. potwierdzają, że dzięki zastosowaniu standardowych algorytmów postępowania umożliwiających trafne zdiagnozowanie stanu metabolicznego i dobór odpowiedniej diety metabotypowanie pozwala na kosztowo efektywne dostarczanie spersonalizowanych porad żywieniowych dla dużych grup odbiorców. Podejście takie sprawdziło się dla zróżnicowanej kulinarnie i kulturowo populacji europejskiej [44]. Autorzy podkreślają, że wykorzystanie fenotypów metabolicznych do spersonalizowanego podejścia żywieniowego wygląda obiecująco, jednak konieczne są dalsze badania z udziałem większej populacji.

Powyższe badania stanowią pierwsze zastosowanie fenotypowania metabolicznego $\mathrm{w}$ dietetyce spersonalizowanej i podkreślają jego ogromny potencjał w dostarczaniu powszechnie dostępnych ukierunkowanych porad żywieniowych.

\section{PODSUMOWANIE}

W randomizowanych badaniach klinicznych wykazano, że udzielanie spersonalizowanych porad żywieniowych ma większą skuteczność w porównaniu do zaleceń uniwersalnych zarówno $\mathrm{w}$ aspekcie zmiany nawyków żywieniowych jak i leczenia otyłości. Fenotypowanie metaboliczne to nowe i dynamicznie rozwijające się pole badawcze, które wydaje się mieć duży potencjał aplikacyjny i może w znaczący sposób przyczynić się do rozwoju dietetyki spersonalizowanej. Liczne badania potwierdziły, że osoby o odmiennych metabotypach różnie reagują na dietę lub określone interwencje żywieniowe. Kolejnym krokiem jest wykorzystanie metabotypowania w tworzeniu spersonalizowanych interwencji żywieniowych. Dotychczas ukazały się dwa artykuły publikujące badania przeprowadzone w ramach projektu Food4Me, w których wykorzystano metabotypowanie do opracowania dostosowanych do potrzeb danego metabotypu zaleceń dietetycznych. Pełne wykorzystanie fenotypowania metabolicznego $\mathrm{w}$ dietetyce wymaga dalszych badań, które wyjaśnią biologiczne mechanizmy warunkujące różnice metaboliczne. Z drugiej strony potrzebne są badania aplikacyjne w szczególności oceniające skuteczność takiego podejścia żywieniowego przy zastosowaniu go na dużych i zróżnicowanych populacjach.

\section{PIŚMIENNICTWO}

1. Palmnäs M, Brunius C, Shi L, et al. (2019) Perspective: Metabotyping- A Potential Personalized Nutrition Strategy for Precision Prevention of Cardiometabolic Disease. Adv Nutr 11: 524-532

2. Hillesheim E, Brennan L (2019) Metabotyping and its role in nutrition research. Nutr Res Rev:1-10

3. Holmes E, Leng Loo R, Stamler J, Bictash M, Yap I, Chan Q et al. (2017) Human metabolic phenotype diversity and its association with diet and blood pressure. Physiol Behav 176: 139-148
4. Goossens G (2017) The Metabolic Phenotype in Obesity: Fat Mass, Body Fat Distribution, and Adipose Tissue Function. Obes Facts 10: 207-215

5. Friston D, Laycock H, Nagy I, Want E (2019) Microdialysis Workflow for Metabotyping Superficial Pathologies: Application to Burn Injury. Anal Chem 91: 6541-6548

6. Brennan L (2016) Metabolomics in nutrition research - A powerful window into nutritional metabolism. Essays Biochem 60: 451-458

7. Everett J, Holmes E, Veselkov K, Lindon J, Nicholson J (2019) A Unified Conceptual Framework for Metabolic Phenotyping in Diagnosis and Prognosis. Trends Pharmacol Sci 40: 763-773

8. Nizel A (1972) Personalized nutrition counseling. ASDC J Dent Child 39: 353-360

9. O'Donovan C, Walsh M, Gibney M, Gibney E, Brennan L (2016) Can metabotyping help deliver the promise of personalised nutrition? Proc Nutr Soc 75: 106-114

10. Ordovas J, Ferguson L, Tai E, Mathers J (2018) Personalised nutrition and health. BMJ 361

11. Bush C, Blumberg J, El-Sohemy A, et al. (2020) Toward the Definition of Personalized Nutrition: A Proposal by The American Nutrition Association. J Am Coll Nutr 39: 5-15

12. Betts J, Gonzalez J. (2016) Personalised nutrition: What makes you so special? Nutr Bull 41: 353-359

13. Tebani A, Bekri S (2019) Paving the way to precision nutrition through metabolomics. Front Nutr 6: 1-10

14. Ferguson L, De Caterina R, Görman U, et al. (2016) Guide and Position of the International Society of Nutrigenetics/Nutrigenomics on Personalised Nutrition: Part 1 - Fields of Precision Nutrition. J Nutrigenet Nutrigenomics 9: 12-27

15. Opracowanie zbiorowe (2011) Toward Precision Medicine. Building a Knowledge Network for Biomedical Research and a New Taxonomy of Disease, The National Academies Press, Washington

16. Ronteltap A, Van Trijp H, Berezowska A, Goossens J (2013) Nutrigenomics-based personalised nutritional advice: In search of a business model? Genes Nutr 8: 153-163

17. Celis-Morales C, Livingstone K, Marsaux C, et al. (2017) Effect of personalized nutrition on health-related behaviour change: Evidence from the Food4Me European randomized controlled trial. Int J Epidemiol 46: 578-588

18. Curtis P, Adamson A, Mathers J (2012) Effects on nutrient intake of a family-based intervention to promote increased consumption of lowfat starchy foods through education, cooking skills and personalised goal setting: The Family Food and Health Project. Br J Nutr 107: 18331844

19. Wright J, Sherriff J, Dhaliwal S, Mamo J (2011) Tailored, iterative, printed dietary feedback is as effective as group education in improving dietary behaviours: Results from a randomised control trial in middle-aged adults with cardiovascular risk factors. Int J Behav Nutr Phys Act 8: 1-12

20. Celis-Morales C, Livingstone K, Marsaux C, et al. (2015) Design and baseline characteristics of the Food4Me study: a web-based randomised controlled trial of personalized nutrition in seven European countries. Genes Nutr 10: 1-13

21. Kroeze W, Oenema A, Dagnelie P, Brug J (2008) Examining the minimal required elements of a computer-tailored intervention aimed at dietary fat reduction: Results of a randomized controlled dismantling study. Health Educ Res 23: 880-891

22. Alexander G, McClure J, Calvi J, et al. (2010) A randomized clinical trial evaluating online interventions to improve fruit and vegetable consumption. Am J Public Health 100: 319-326

23. Hutchesson M, Collins C, Morgan P, Watson JF Guest M, Callister R (2014) Changes to dietary intake during a 12-week commercial webbased weight loss program: A randomized controlled trial. Eur J Clin Nutr 68: 64-70

24. Ambeba E, Systems C, Ye L, et al. (2016) Reported Energy and Fat Intake. J Cardiovasc Nurs 30: 35-43 
25. Springvloet L, Lechner L, De Vries H, Candel M, Oenema A (2015) Short-and medium-term efficacy of a web-based computer-tailored nutrition education intervention for adultsincluding cognitive and environmental feedback: Randomized controlled trial. J Med Internet Res 17: 23

26. Tate D, Jackvony E, Wing R (2006) A randomized trial comparing human e-mail counseling, computer-automated tailored counseling, and no counseling in an internet weight loss program. Arch Intern Med 166: $1620-1625$

27. Hunter C, Peterson A, Alvarez L, et al. (2008) Weight Management Using the Internet. A Randomized Controlled Trial. Am J Prev Med 34: $119-126$

28. Bennett G, Herring S, Puleo E, Stein E, Emmons K, Gillman M (2010) Web-based weight loss in primary care: A randomized controlled trial. Obesity 18: 308-313

29. Seo D, Niu J (2015) Evaluation of internet-based interventions on waist circumference reduction: A meta-analysis. J Med Internet Res 17: 1-13

30. Lewis Z, Lyons E, Jarvis J, Baillargeon J (2015) Using an electronic activity monitor system as an intervention modality: A systematic review Health behavior, health promotion and society. BMC Public Health 15: 1-15

31. Morgan P, Callister R, Collins C, et al. (2013) The SHED-IT community trial: A randomized controlled trial of internet- and paper-based weight loss programs tailored for overweight and obese men. Ann Behav Med 45: 139-152

32. Arkadianos I, Valdes A, Marinos E, Florou A, Gill R, Grimaldi K (2007) Improved weight management using genetic information to personalize a calorie controlled diet. Nutr 6: 1-8

33. Bloss C, Schork N, Topol E (2011) Effect of direct-to-consumer genomewide profiling to assess disease risk. N Engl J Med 364: 524-534

34. Bloss C, Wineinger N, Darst B, Schork N, Topol E (2013) Impact of direct-to-consumer genomic testing at long term follow-up. J Med Genet 50: $393-400$

35. Grant R, O'Brien K, Waxler J, et al. (2013) Personalized genetic risk counseling to motivate diabetes prevention: A randomized trial. Diabetes Care 36: 13-19

36. Nielsen D, El-Sohemy A (2014) Disclosure of genetic information and change in dietary intake: A randomized controlled trial. PLoS One 9: $1-8$

37. Frankwich K, Egnatios J, Kenyon M, et al (2017) Differences in Weight Loss Between Persons on Standard Balanced vs Nutrigenetic Diets in a Randomized Controlled Trial. Physiol Behav 176: 139-148

38. Jafarzadeh-Esfehani R, Vojdani S, Hashemian S, et al. (2020) Genetic variants of the phenylalanine hydroxylase gene in patients with phenylketonuria in the northeast of Iran. J Pediatr Endocrinol Metab 33: 355-359

39. Klepper J, Diefenbach S, Kohlschütter A, Voit T (2004) Effects of the ketogenic diet in the glucose transporter 1 deficiency syndrome. Prostaglandins Leukot Essent Fat Acids 70: 321-327

40. O’Donovan C, Walsh M, Gibney M, Brennan L, Gibney E (2017) Knowing your genes: Does this impact behaviour change? Proc Nutr Soc 76: 182-191

41. Chao S, Roberts J, Marteau T, Silliman R, Cupples L, Green R (2008) Health behavior changes after genetic risk assessment for Alzheimer disease: The REVEAL study. Alzheimer Dis Assoc Disord 22: 94-97

42. Holzapfel C, Drabsch T (2019) A scientific perspective of personalised gene-based dietary recommendations for weight management. Nutrients 11: 1-14

43. Marteau T, French D, Griffin S, Prevost A, Sutton S, Watkinson C (2010) Effects of communicating DNA-based disease risk estimates on risk-reducing behaviours. Cochrane Database Syst Rev 10: 1-56

44. O'Donovan C, Walsh M, Woolhead C, et al. (2017) Metabotyping for the development of tailored dietary advice solutions in a European population: the Food4Me study. Br J Nutr 118: 561-569

45. Riedl A, Wawro N, Gieger C, et al. (2018) Identification of Comprehensive Metabotypes Associated with Cardiometabolic Diseases in the Population-Based KORA Study. Mol Nutr Food Res 62: 1-14
46. Beger R, Dunn W, Schmidt M, et al. (2016) Metabolomics enables precision medicine: "A White Paper, Community Perspective." Metabolomics 12: 1-15

47. Fiamoncini J, Rundle M, Gibbons H, et al. (2018) Plasma metabolome analysis identifies distinct human metabotypes in the postprandial state with different susceptibility to weight loss-mediated metabolic improvements. FASEB J 32: 5447-5458

48. Hjorth M, Zohar Y, Hill J, Astrup A (2018) Personalized Dietary Management of Overweight and Obesity Based on Measures of Insulin and Glucose. Annu Rev Nutr 38: 245-272

49. Wang T, Edwards A, Clevidence B (2013) Strong and weak plasma response to dietary carotenoids identified by cluster analysis and linked to beta-carotene $15,15^{\prime}$-monooxygenase 1 single nucleotide polymorphisms. J Nutr Biochem 24: 1538-1546

50. Vázquez-Fresno R, Llorach R, Perera A, et al. (2016) Clinical phenotype clustering in cardiovascular risk patients for the identification of responsive metabotypes after red wine polyphenol intake. J Nutr Biochem 28: 114-120

51. O'Donovan C, Walsh M, Nugent A, et al. (2015) Use of metabotyping for the delivery of personalised nutrition. Mol Nutr Food Res 59: $377-$ 385

52. Wang-Sattler R, Yu Z, Herder C, et al. (2012) Novel biomarkers for pre-diabetes identified by metabolomics. Mol Syst Biol 8: 1-11

53. Rizza S, Copetti M, Rossi C, et al. (2014) Metabolomics signature improves the prediction of cardiovascular events in elderly subjects. Atherosclerosis 232: 260-264

54. Jové M, Mauri-Capdevila G, Suárez I, et al. (2015) Metabolomics predicts stroke recurrence after transient ischemic attack. Neurology 84: 36-45

55. Ventura A, Loken E, Birch L (2006) Risk profiles for metabolic syndrome in a nonclinical sample of adolescent girls. Pediatrics 118: 24342442

56. Kirchberg F, Grote V, Gruszfeld D, et al. (2019) Are all breast-fed infants equal? Clustering metabolomics data to identify predictive risk clusters for childhood obesity. J Pediatr Gastroenterol Nutr 68: 408-415

57. Hussain T, Mathew T, Dashti A, Asfar S, Al-Zaid N, Dashti H (2012) Effect of low-calorie versus low-carbohydrate ketogenic diet in type 2 diabetes. Nutrition 28: 1016-1021

58. Shyam S, Arshad F, Abdul Ghani R, et al. (2013) Low glycaemic index diets improve glucose tolerance and body weight in women with previous history of gestational diabetes: A six months randomized trial. Nutr J 12: 1-12

59. Hjorth M, Ritz C, Blaak E, et al. (2017) Pretreatment fasting plasma glucose and insulin modify dietary weight loss success: Results from 3 randomized clinical trials. Am J Clin Nutr 106: 499-505

60. Li D (2017) Effects of Macronutrient Distribution on Weight and Related Cardiometabolic Profile in Healthy Non-Obese Chinese: A 6-month, Randomized Controlled-Feeding Trial. EBioMedicine 22: 200-207

61. Turnbaugh P, Ley R, Mahowald M, Magrini V, Mardis E, Gordon J (2006) An obesity-associated gut microbiome with increased capacity for energy harvest. Nature 444: 1027-1031

62. A de Luis D, Aller R, Izaola O, Gonzalez Sagrado M, Conde R (2006) Differences in glycaemic status do not predict weight loss in response to hypocaloric diets in obese patients. Clin Nutr 25: 117-122

63. Ballesteros-Pomar M, Calleja-Fernndez A, Vidal-Casariego A, Urioste-Fondo A, Cano-Rodrguez I (2010) Effectiveness of energy-restricted diets with different protein:carbohydrate ratios: The relationship to insulin sensitivity. Public Health Nutr 13: 2119-2126

64. Pittas A, Das S, Hajduk C, et al. (2005) A low-glycemic load diet facilitates greater weight loss in overweight adults with high insulin secretion but not in overweight adults with low insulin secretion in the CALERIE trial. Diabetes Care 28: 2939-2941

65. Chaput J, Tremblay A, Rimm E, Bouchard C, Ludwig D (2008) A novel interaction between dietary composition and insulin secretion: Effects on weight gain in the Quebec Family Study. Am J Clin Nutr 87: 303309 
66. Ebbeling C, Leidig M, Feldman H, Lovesky M, Ludwig D (2007) Effects of a low-glycemic load vs low-fat diet in obese young adults: A randomized trial. J Am Med Assoc 297: 2092-2102

67. Gardner C, Trepanowski J, Gobbo L, et al. (2018) Effect of low-fat VS low-carbohydrate diet on 12-month weight loss in overweight adults and the association with genotype pattern or insulin secretion the DIETFITS randomized clinical trial. JAMA - J Am Med Assoc 319: 667679

68. Stephan C, Hill A, Xi N, Delft Y van, Moecklinghoff C (2012) Adherence to a low-fat vs. low-carbohydrate diet differs by insulin resistance status. JAIDS J Acquir Immune Defic Syndr 61: 73-75
69. Rock C, Flatt S, Pakiz B, et al. (2018) Effects of diet composition on weight loss, metabolic factors and biomarkers in a 1-year weight loss intervention in obese women examined by baseline insulin resistance status. Metabolism 65: 1605-1613

70. Vazquez-Vidal I, Desmarchelier C, Jones P (2019) Nutrigenetics of Blood Cholesterol Concentrations: Towards Personalized Nutrition. Curr Cardiol Rep 21: 1-5

\title{
Metabolic phenotyping in the development personalized nutrition
}

\author{
Mateusz Grabowski ${ }^{1,2}$, Jarosław Barski ${ }^{1,2}$, Daniela Liśkiewicz ${ }^{2,3} \square$ \\ ${ }^{1}$ Department for Experimental Medicine, Medical University of Silesia in Katowice \\ ${ }^{2}$ Department of Physiology, School of Medicine, Medical University of Silesia in Katowice \\ ${ }^{3}$ Laboratory of Molecular Biology, The Jerzy Kukuczka Academy of Physical Education in Katowice \\ $\square_{\text {corresponding author: d.liskiewicz@awf.katowice.pl }}$
}

Key words: personalized nutrition, metabolic phenotyping, metabotyping, metabolomics, metabotype, metabolome

\section{ABSTRACT}

Diet is an important modifiable lifestyle factor affecting the risk of developing of most non-communicable diseases. A properly selected diet protects against the development of many diseases or supports their treatment. Randomized clinical trials have shown that personalized nutrition is more effective than general nutritional advice in terms of changing eating habits and treating obesity. Depending on the degree of diversification of dietary recommendations and their adaptation to the individuals' needs, one can differentiate: stratified, personalized and precise nutrition. Metabolic phenotyping - grouping people based on their metabolic characteristics - is a relatively new research field which may have a great value in the development of personalized nutrition. Many studies have shown that people with different metabotypes react differently to a diet or specific nutritional interventions. This article reviews current studies regarding the possibility of using the metabolic phenotyping in stratified and personalized nutrition. The article presents methods for creating metabolic phenotypes, diagnostic and prognostic research involving metabotyping and research that use metabotyping for the delivery of targeted dietary advice conducted so far. 